\title{
Клінічний випадок лікування кровохаркання у дорослого пацієнта із синдромом Ейзенменгера шляхом закриття системно-легеневих колатеральних артерій
}

\author{
Радченко М. П., Довгалюк А. А., Кузьменко Ю. Л., Руденко Н. М. \\ ДУ «Науково-практичний медичний центр дитячої кардіології та кардіохірургії МОЗ України» (Київ)
}

\begin{abstract}
Розширені бронхіальні артерії та системно-легеневі колатеральні артерії (аортолегеневі колатеральні артерії) можуть бути однією з причин кровохаркання та супроводжувати вроджені вади серця (ВВС). Діагностувати наявність цих судини можна за допомогою селективної ангіографії. Мета роботи - представити клінічний випадок успішного лікування кровохаркання шляхом ендоваскулярного закриття системно-легеневих колатеральних артерій у дорослого пацієнта. Матеріали та методи. Пацієнт спостерігається в Центрі дитячої кардіології та кардіохірургії з 2014 р., висуває скарги на задишку, втомлюваність, ціаноз шкірних покривів. Кровохаркання з частотою декілька разів на місяць після мінімальних фізичних навантажень відмічає протягом останніх двох місяців. Результати. Пацієнту проведено ендоваскулярне втручання із закриття системно-легеневих колатералей. При контрольній графії кровотік через емболізовані ділянки відсутній. Для такої когорти пацієнтів зі складною вродженою вадою серця, ускладненою легеневою гіпертензією, вирішенням даної проблеми є ендоваскулярне втручання. Висновки. Емболізація системно-легеневих колатеральних артерій є ефективною процедурою для лікування пацієнтів із кровохарканням.
\end{abstract}

Ключові слова: системно-легеневі колатеральні артерії, кровохаркання, ендоваскулярне лікування.

Кровохаркання може бути результатом різних причин: туберкульозу легень, бронхогенної карциноми і хронічних запальних захворювань легень, пневмонії, пневмоконіозу, аортобронхіальних нориць, розриву аневризми аорти та бронхіальних артерій [1]. Даний клінічний симптом зустрічається з частотою близько $1,5 \%[2]$.

Розширені бронхіальні артерії та системно-легеневі колатеральні артерії (аортолегеневі колатеральні артерії) можуть бути однією з причин кровохаркання та супроводжувати вроджені вади серця (BBC) - такі, як атрезія легеневої артерії, транспозиція магістральних судин та інші [1]. Діагностувати наявність цих судини можна за допомогою ехокардіографії, проте остаточно діагноз верифікується за даними комп'ютерної томографії та селективної ангіографії.

Поєднання у дорослих неоперованих пацієнтів ВВС із клінікою кровохаркання зустрічається вкрай рідко. В літературі описано лише декілька таких випадків [3].

Мета роботи - представити клінічний випадок успішного лікування кровохаркання шляхом ендоваскулярного закриття системно-легеневих колатеральних артерій у дорослого пацієнта із вродженою вадою серця - спільним артеріальним стовбуром І типу з високою легеневою гіпертензією, синдромом Ейзенмейгера та системно-легеневими колатеральними артеріями.

Матеріали та методи. Чоловік, віком 31 рік, спостерігається в Центрі дитячої кардіології та кардіохірургії з 2014 р. $з$ діагнозом: вроджена вада серця у дорослих, спільний артеріальний стовбур, I типу; помірна недостатність клапана спільного артеріального стовбура; висока легенева гіпертензія; системно-легеневі колатералі від низхідної аорти. СН ІІБ. NYHА III. Про вроджену ваду серця відомо з народження. За медичною допомогою батьки пацієнта звернулись в той час, коли вада серця вже була неоперабельною через склеротичні зміни судин легень. Висуває скарги на задишку, втомлюваність, ціаноз шкірних покривів. Весь час почував себе відносно задовільно. Кровохаркання з частотою декілька разів на місяць після мінімальних фізичних навантажень відмічає протягом останніх двох місяців, що потребувало госпіталізації в спеціалізовані стаціонари та проведення бронхоскопії.

Постійно отримує медикаментозну терапію (силденафіл у дозі 25 мг/кг тричі на добу). Обстежений на предмет легеневої гіпертензії. За даними катетеризації серця та магістральних судин, тиск у легеневій артерії складав 100/60 (80) мм рт. ст. при системному 100/60 (80) мм рт. ст. Cardiac Output -2.86 L/min. Cardiac Index -1.86 L/min/mI. PVR=12.62 од.* ${ }^{2}$. При проведенні інгаляційної проби 3 препаратом «Вентавіс» отримано такі дані: тиск у легеневій артерії складав 100/60 (80) мм рт. ст. при системному 103/60 (81) мм рт. ст. Cardiac Output - $2.98 \mathrm{~L} / \mathrm{min}$. Cardiac Index - $1.94 \mathrm{~L} / \mathrm{min} / \mathrm{mI}$. PVR=11.36 од. ${ }^{2}{ }^{2}$ Ангіографічні ознаки склеротичних змін у легеневих судинах. Насичення крові киснем, за даними пульсоксиметрії, складало 82-86\%. Гемоглобін на момент обстежен- 

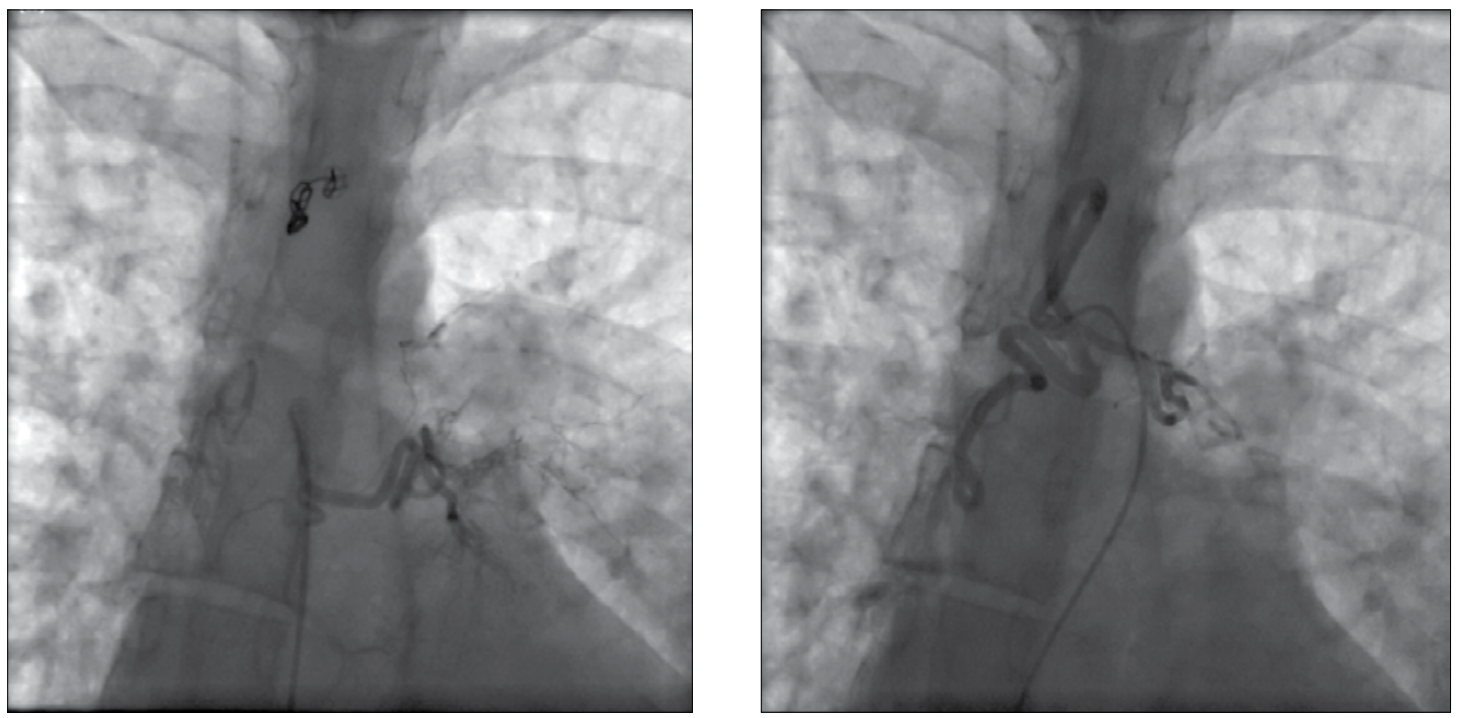

Рис 1. Системно-легенева колатераль (1), що поділяється на дві гілки.

Системно-легеневі колатералі (2)

ня - 177 г/л. Аортографія в 2014 р., при першому агіографічному обстеженні, не проводилася, на той час пацієнт не висував зазначених вище скарг. Симптоми кровохаркання з'явилися в 2017 р. Для виявлення причини кровохаркання пацієнту проведена комп'ютерна томографія та бронхоскопія з метою диференціальної діагностики, обстежений на туберкульоз. При повторному зверненні та обстеженні в динаміці при графії $з$ низхідної аорти візуалізовано дві системно-легеневі колатералі до правої та лівої легені (рис. 1).

Результати. Пацієнту проведено ендоваскулярне втручання $з$ доступу arteria femoralis dextra 5 Fr. Koлатераль (1), що поділяється на дві гілки до правої та лівої легені, закрито системою Cook Embolization coil
NESTER 6 mm, системами Cook Embolization coil NESTER $5 \mathrm{~mm}$ та MReye $5 \mathrm{~mm}$. Кровотік через емболізовану ділянку судини мінімальний, при контрольній графії через 5 хвилин - відсутній. Колатераль (2) до лівої легені закрито системою Tornado $4 * 3 \mathrm{~mm}$. При контрольній графії кровотік через емболізовану ділянку відсутній (рис. 2).

В післяопераційному періоді пацієнт одну добу перебував у відділенні інтенсивної терапії, медикаментозно отримував силденафіл, гепарин і цефуроксим. Виписаний у відносно задовільному стані через 3 доби після втручання. Ні в післяопераційному періоді, ні за період амбулаторного спостереження терміном 8 місяців скарг на кровохаркання пацієнт не висуває.
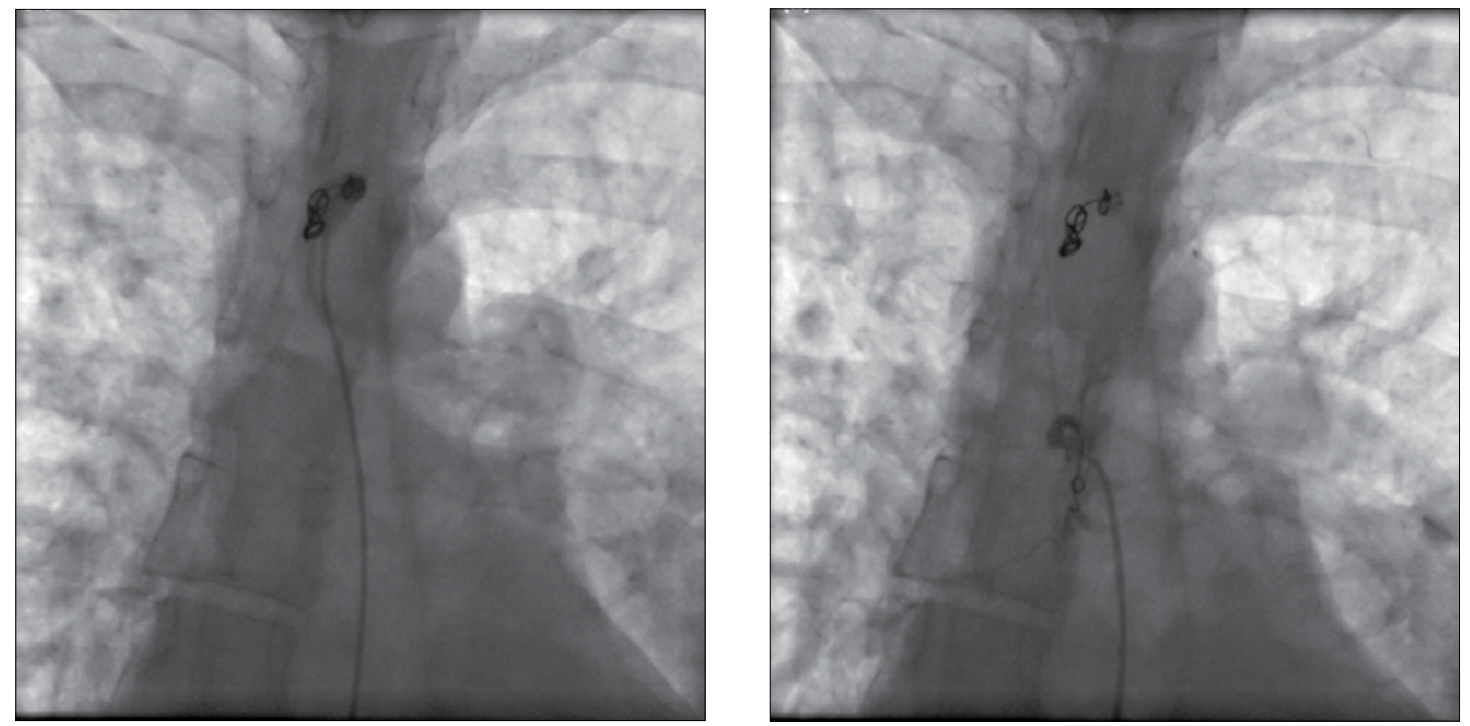

Рис. 2. Результат закриття системно-легеневих колатералей системами Соok 
Для такої когорти пацієнтів зі складною вродженою вадою серця, ускладненою легеневою гіпертензією, єдиним вирішенням даної проблеми є ендоваскулярне втручання.

\section{Висновки}

1. Емболізація системно-легеневих колатеральних артерій є безпечною та ефективною процедурою для лікування пацієнтів із кровохарканням.

2. Діагностичний протокол зондування порожнин серця у пацієнтів із вродженими вадами серця зі скаргами на кровохаркання має включати контрастування низхідної аорти для виключення системнолегеневих колатералей як причини кровохаркання.

\section{Література}

1. Bronchial artery embolisation in management of hemoptysis - A retrospective analysis in a tertiary university hospital / H. Daby, R. Gomes, A. Marinho et al. // Pneumologia. - $2016-22$ (1). - P. 34-38.

2. David R. Sopko, Tony P. Smith. Bronchial Artery Embolization for Hemoptysis // Seminars in interventional radiology. - 2011. - Vol. 28, N 1.

3. Endovascular treatment of haemoptysis: Medium and long-term assessment / H. Racil, H. Rajhi, R. Ben Naceur et al. // Diagnostic and Interventional Imaging. - 2013. 94. - P. 38-44.

\title{
Clinical case of treatment of hemoptysis in an adult patient with Eisenmenger syndrome by closing systemic pulmonary collateral arteries
}

\author{
Radchenko M. P., Dovgalyuk A. A., Kuzmenko Yu. L., Rudenko N. M. \\ Ukrainian Children's Cardiac Center (Kyiv)
}

Dilated bronchial arteries and systemic to pulmonary collateral arteries (aorto-pulmonary collateral arteries) can cause hemoptysis and accompany congenital heart defects (CHD). For diagnostic verification of aforementioned vessels selective angiography is method of choice. The purpose of this article is to present a clinical case of successful hemoptysis treatment by endovascular closure of systemic to pulmonary collateral arteries in an adult patient. Material and methods. Patient has been observed at the Ukrainian Children's Cardiac Center from 2014, among complains: shortness of breath, fatigue, and cyanosis. For last two months patient had frequent episodes of hemoptysis after minimal physical activity. Results. Patient undergone an endovascular intervention with the closure of the systemic to pulmonary collaterals. On control angiography blood flow through occluded systemic to pulmonary arteries has been absent. For patients with complex congenital heart disease, complicated by pulmonary hypertension, the solution of this problem is endovascular intervention. Conclusion. Embolization of systemic to pulmonary collateral arteries is an effective procedure for treating patients with haemoptysis.

Key words: systemic pulmonary collateral arteries, hemoptysis, endovascular treatment. 